УДК 351:371.1'437.6

\title{
Аержавне управління вищою освітою Словаччини: реформи у контексті європейської інтеграції
}

\author{
I.O. АЕГТЯРЬОВА \\ Аніпропетровський регіональний інститут Аержавного управління \\ Національної акалемії державного управління при Презилентові України, \\ м. Аніпропетровськ, Україна, E-mail: irenkadnepr@ukr.ne†
}

\section{Авторське резюме}

Метою статті є узагальнення досвіду реформування державного управління вищою освітою у Словаччині, що відбувалося одночасно з процесами суспільно-політичних перетворень країни, інтеграції до Європейського Союзу та формування Європейського простору вищої освіти, що на сьогодні є дуже актуальним у контексті реформування національної системи вищої школи. Проаналізовано законодавчу базу вищої освіти Словаччини і шляхи децентралізації та демократизації управління за 15 p. (1990-2015 рр.). Основними рисами Закону про вищу освіту Чехословаччини від 1990 р. були такі: демонополізація системи вищої освіти, демократизація та децентралізація управління, i на рівні ВНЗ зокрема, включаючи гарантії академічних прав і свобод, широку автономію та статус юридичної особи для факультетів та ін. Схарактеризовано процес подальших складних реформувань у період 1990-2002 pp., який завершився ухваленням нового Закону про вищу освіту 2002 р. Показано ключові зміни на системному та інституційному рівнях, зокрема щодо фінансової автономії ВНЗ (право власності на нерухоме майно) та участь зовнішніх органів управління (Наглядова рада). Дослідження побудовано на оригінальних джерелах - нормативно-правовій базі з вищої освіти та дослідженнях словацьких науковців. Детально схарактеризовано систему державного управління вищою освітою: повноваження держави (уряду, міністерства) на рівні системному та вплив на інституційний рівень функціонування вищої освіти. Показано форму участі та роль академічної громадськості в управлінні у сфері вищої освіти та виробленні освітньої політики Словацької Республіки. Досвід Словаччини є прикладом добрих практик у сфері врядування, зокрема тимчасових кроків у період трансформації та демократизації.

Ключові слова: закон про вищу освіту, державне управління, Словаччина, реформа, міністерство, представницькі органи, освітня політика, демократизація, децентралізація.

\section{Governance in higher education in Slovakia: reforms within the paths of European integration}

\author{
I.O.DEGTYAROVA \\ Dnepropetrovsk regional institute of public administration, the National \\ academy of public administration, office of the President of Ukraine, \\ Dnipropetrovsk, Ukraine, E-mail: irenkadnepr@ukr.net
}

\begin{abstract}
The aim of this article is to summarize the experience of higher education governance reforms in Slovakia, which were taking place along with the processes of social and political transitions of the country, its integration paths towards the European Union and development of the European Higher Education Area, which is highly important in the context of reforming of the national system of higher education. We analyzed the legal framework in higher education in Slovakia and ways of decentralization and democratization in governance for 15 years (1990-2015). The main characteristics of the Czechoslovakia Law on Higher Education adopted in 1990 are the following: demonopolization,

(c) I.О. Дегтярьова, 2015
\end{abstract}


decentralization of governance, and particularly on the university level, i.e. guarantying of the academic freedoms and rights, increasing the autonomy and legal entity rights for the faculty, etc. We analyzed complex process of further reforms held during the 19902002, which was culminated by the adoption of the new Law on Higher Education in 2002. Key changes were implemented in the system and institutions, including granting bigger financial autonomy to universities (immovable property ownership rights) and the participation of external board in the university management (Board of Trustees). The study is based on the authentic sources: the legal framework of higher education and researches of Slovak academics. Author described the system of governance in higher education: authority of the state (Government, Ministry) and their influence on the university performance. The participation and the role of academic stakeholders is revealed in higher education governance and development of educational policy in the Slovak Republic. Slovakia's experience is considered to be a good practice in higher education governance, particularly temporary measures in the transformation and democratization period.

Keywords: law on higher education, governance, Slovakia, reform, Ministry, representative bodies, educational policy, democratization, decentralization.

Постановка проблеми. На шляху до Європейського Союзу посткомуністичні країни пройшли складні процеси соціально-економічних та політичних трансформацій, здійснили реформи основних сфер функціонування держави і суспільства, що ставали викликами як для самої національної еліти тієї чи іншої країни, так і їі громадян. Реформування системи вищої освіти та державного управління галуззю відбувалися у контексті євроінтеграційних трансформацій та інтеграції до Болонського процесу. I саме досвід країн Центральної та Східної Європи, зокрема Вишеградської четвірки, як-от: Польщі, Угорщини, Чехії та Словаччини доцільно вивчати з особливим акцентом на шляхи та механізми реформування державного управління вищою освітою, адже у кожній країні вони мали свої особливості, різну динаміку, різні академічні традиціі та різний політичний контекст. Для повного уявлення всіх трансформаційних процесів у сфері державного управління вищою освітою варто детально вивчати досвід і невеликих країн, і зокрема Словаччини, яка у складі Чехословаччини у 1990 р. ухвалила новий закон «Про вищу освіту», проте формально незалежною стала у 1993 р., а відтак мала свої національні виклики, які успішно долає по сьогодні. У науці державного управління, та й в українській освітології, бракує досліджень системи державного управління вищою освітою та розвідок про реформування вищої освіти у Словаччині, що й обумовлює актуальність обраної тематики.

Аналіз досліджень і публікацій. Зарубіжний досвід організації та реформування системи вищої освіти сьогодні аналізується і вивчається досить широко науковцями, громадськими експертами та управлінцями (Л. Гриневич, Д. Дзвінчук, М. Згуровський, О. Карпенко, С. Квіт, М. Карпуленко, В. Луговий, В. Майборода, Л. Прокопенко, В. Сацик, I. Сікорська, I. Совсун, Є. Стадний, Т. Фініков, О. Шеломовська та ін.), але практично немає грунтовних досліджень освітньої політики та системи державного управління вищою освітою у Словацькій Республіці. Хоча, у загальному контексті характеристики зарубіжного досвіду трапляються поодинокі посилання на словацький досвід, у контексті країн Центральної та Східної Європи (В. Майборода, І.Сікорська, В.Сацик та ін.). Більше на зазначеній проблематиці сфокусовано праці зарубіжних учених, насамперед словацьких: Е. Бенова, М. Фабус, 2012; Д. Малова, Е. Ластін, 2000; Б. Косова, С. Порубскі, 2007; П. Медерлі, 2013; А. Капланова, 2000, Р. Кралікова, 2015, О. Кананикіна, 2013 та ін. Зокрема Е. Бенова та М. Фабус (2012) аналізують демократизаційні трансформації у системі вищої освіти, у моделях управління за трьома ключовими подіями та етапами: перший Закон про вищу освіту 1990 р., другий Закон про вищу освіту 2002 р. та інтернаціо- 
налізація вищої освіти Словаччини (сучасний етап) [2]. Автори зауважують, що процес демократизації і комплексна реформа вищої освіти вплинули на демократичні перетворення у Словаччині. Досить критично оцінюе процес трансформацій у системі вищої освіти за період 1989-2000 рр. у плані лібералізації, демократизації управління та збільшення академічної автономії Д.Малова [6]. П. Медерлі акцентує на тому, що реформування системи вищої освіти було скеровано насамперед на 4 цілі: доступ до вищої освіти, якість, автономія ВНЗ і відповідальність/підзвітність [7]. Важливим для аналізу управління освітою та процесів трансформації у Словаччині $\epsilon$ дослідження Р. Кралікової, зокрема його соціологічна складова та результати індивідуальних інтерв'ю з представниками основних стейкхолдерів та осіб, які безпосередньо брали участь у законотворчому процесі та процесі вироблення освітньої політики у Словаччині протягом 19902002 pр. та у сучасний період, серед яких і урядовці, і керівники національних студентських, ректорських об'єднань та ін. [5]. Великої дослідницької уваги варті публікації, зроблені за результатами досліджень у рамках європейських проектів Європейської асоціації університетів (зокрема «Університетська автономія в Європі»), Еразмус, Темпус, а також національні звіти та аналітичні документи Словацької конференції ректорів, ЮНЕСКО, дослідження Світового банку та Європейської організації економічного співробітництва та розвитку (OECD). Саме ці праці та актуальна нормативно-правова база стали джерелом для аналізу системи управління і трансформацій у сфері вищої освіти Словаччини.

Мета дослідження - узагальнити досвід реформування державного управління вищою освітою у Словаччині у контексті європейської інтеграції та входження до Свропейського простору вищої освіти, проаналізувати законодавчу базу вищої освіти Словаччини і шляхи децентралізації та демократизації управління у системі за 15 р. (1990-2015 рp.).

Виклад основного матеріалу. Варто зауважити, що Україна та Сло- ваччина мають одну вихідну точку - початок 90-х рр., схожу модель державного управління в минулому - тоталітарна, авторитарна централізована вертикаль державної влади, схожі механізми вироблення освітньо-наукової політики та умови функціонування системи вищої освіти і т.д. Для аналізу державного управління вищою освітою та системних трансформацій слід чітко розуміти структуру системи вищої освіти Словаччини на сьогодні.

1. Загальна характеристика системи. За актуальними даними Міністерства освіти, науки, досліджень і спорту Словацької Республіки в країні 3 населенням 5,2 млн. мешканців функціонують 36 вищих навчальних закладів, з них 20 - публічні (державні, які фінансуються 3 державного бюджету), 13 - приватні, 3 - державні спеціалізовані (військовий, поліцейський, медичний заклади), крім того, у Словацькій Республіці діють п'ять закордонних університетів (4 чеські та 1 німецький університет) [7; 13; 14]. Станом на 2012/2013 навчальний рік у вищих навчальних закладах Словаччини навчалися 205000 студентів: у публічних - 165000 , приватних - 36000 , державних спеціалізованих - 4 000. Найбільшим навчальним закладом є Університет Коменського у Братиславі, в якому навчається 28000 студентів $[7 ; 13 ; 14]$. Словаччина, як і багато посткомуністичних країн, зберегла 2 наукові ступені - доктор філософiï PhD (до 1997 р. - Kandidát Vied (CSc) та доктор наук (Doktor vied, DrSc) [7; 13; $14]$.

2. Реформування нормативно-правової бази і трансформації у моделі державного управління вищою освітою.

2.1. Етап посткомуністичних трансформацій: демонополізація, децентралізація, масовизація та регіоналізація вищої освіти. Перший Закон про вищу освіту (1990р.). У 1990 р. Чехословаччина першою ухвалила некомуністичний Закон про вищу освіту, який був спрямований на децентралізацію, деідеологізацію, зменшення політизації управління та контролю, на впровадження академічних прав і свобод та унезалежнення університетів і факультетів, що набували 
повної академічної автономії. А деполітизації факультетів сприяла запроваджена виборність деканів факультетів та його підзвітність раді факультету, яка обирала та звільняла декана, що обумовило значне зменшення адміністративного впливу та тиску керівника навчального закладу.

Учені визначають такі ключові системні риси першого Закону про вищу освіту: кількісні параметри розвитку вищої освіти (кількість університетів виросла до 36), ліквідація централізованого управління вищою школою, формування університетів 3 академічними правами та свободами та як автономних інституцій, яким гарантовано свободу наукових досліджень і публікація їх результатів, диверсифікація вищої освіти [2; 7]. Децентралізація стосувалася не лише університету відносно міністерства, а й факультету на рівні ВНЗ. За твердженням експертів, саме факультети, декани відіграли ключову роль на початку перетворень, адже саме вони стали ключовими експертами у ході громадського обговорення законопроекту на національному рівні в Раді з вищої освіти. Факультети отримали статус юридичної особи. Науковці зауважують, що такі кроки були необхідними, оскільки рівень недовіри та розчарування у державі та центральному управлінні, а також у централізованому університетському менеджменті (ректорах) та центральних ініціативах був високим, оскільки ректорів призначала комуністична партія, що вимагало їх лояльності до політичного режиму [1].

I хоча подальший процес роботи над законодавством, як свідчать словацькі дослідники (Д. Малова, Р. Кралікова), проходив із залученням представників різних категорій академічної громадськості, але міністерство постійно прагнуло зміцнити своє право втручатися у функціонування університетів, порушуючи права останніх на автономію. Тому цей період деякі вчені називають балансуванням між університетською автономією та впливом держави [6].

У 1996 р. Міністерство підготувало «Стратегічний план для університетів» - стратегія децентралізації системи вищої освіти, їі регіоналізації, за яким уні- верситети мусили бути утворені в усіх 8 адміністративних центрах Словаччини після адміністративно-територіальної реформи. Ці дії викликали неоднозначну реакцію від академічного середовища, яке вбачало у цьому певні політичні кроки [6]. У 1998 р. новий уряд декларує необхідність глибокого реформування вищої освіти та завершити ті зміни, які розпочалися у $1990 \mathrm{p}$.

2.2. Європеїзація вищої освіти: Болонський процес, приєднання до $\mathrm{CC}$ та другий Закон про вищу освіту 2002 p. Головне реформування системи вищої освіти Словаччини відбулося у 2002 p., але цьому передували низка подій та боротьба за університетську автономію. У 1999 р. Словаччина підписала Болонську декларацію. Стратегія імплементації принципів Болонської декларації була визначена уже в 2000 р. в Урядовому програмному документі «Концепція розвитку вищої освіти у Словаччині XXI століття» у 2000 р. та Програмній декларації Уряду у 2002 р. Саме ці документи, а також положення Декларації ЮНЕСКО про вищу освіту (1998) та приклад Чеського закону про вищу освіту [5, с.20] було покладено в основу розроблення нового Закону про вищу освіту, який було ухвалено у 2002 р. Відповідно до нового Закону про вищу освіту було значно підвищено автономію вищих навчальних закладів, натомість зменшено вплив держави на їх інституційне функціонування. Р.Кралікова зауважує, що досягненням Закону є те, що "до управління вищою освітою залучалися зовнішні стейкхолдери та запроваджувалися гнучкі фінансові механізми» $[5$, с. 8$]$.

Цілі реформи 2000-х рр. були - реалізувати Болонські принципи, змінити економічні умови функціонування вищих навчальних закладів, зміцнити зв'язки між вищою освітою і суспільством. Міністерство створює умови для розвитку вищої освіти відповідно до довгострокової стратегії розвитку системи вищої освіти, яка оновлюється і корегується щорічно відповідно до поточних ситуацій. Виходячи з цього, вищі навчальні заклади створюють власні академічні профілі та стра- 
тегії розвитку шляхом переговорів між окремим закладом та міністерством.

У 2002 р. акцент з факультетів було зміщено на рівень університету, оскільки, з одного боку, виникла потреба консолідації університетів і централізації управління ВНЗ, тому було скасовано автономію факультетів (статус юридичної особи), а з іншого боку - відбувалися процеси фінансової автономізації університетів та передача права власності на нерухоме майно, і постала загроза розпаду університетів за умови збереження автономії факультетів, отже, власником майна має бути університет.

За новим Законом державні вищі навчальні заклади отримали законне право на володіння власністю у 2003 р. і право брати позики з 2002 р. (останнє було скасовано у 2005 р.) і стали самоврядними організаціями, але які мають наглядовий орган управління, що призначається ззовні (міністерством) - Наглядова/ Піклувальна рада, але вона має обмежені повноваження, що стосуються в основному питань, пов'язаних з розпорядженням майном та заснуванням юридичних осіб (тоді потрібна обов'язкова згода Наглядової ради), хоча вона може висловлювати свою позицію щодо різних питань, проте не втручається у навчально-педагогічний процес. Таким чином, Міністерство створило механізм та орган зовнішнього громадського управління, який деякі дослідники вважають органом опосередкованого впливу держави на вирішення фінансових питань, зокрема продажу/ купівлі нерухомості, але разом з тим, незважаючи на слабку законодавчу базу такого державно-громадського партнерства, така модель управління допомогла зберегти і зміцнити матеріальну базу, знижуючи ризики корупційних діянь. Протягом кількох років продовжувалася тенденція до збільшення автономії вищих навчальних закладів. Що стосується залучення зацікавлених сторін, і особливо щодо розробки нових навчальних програм, була посилена позиція членів правління та університетських рад вищих навчальних закладів, а також зміцнилася роль національних громадських консультативних органів у процесі управління та функціонування системи вищої освіти. У 2003-2004 р. було внесено зміни до закону з метою гармонізувати з законодавством СС певні важливі сфери, зокрема адаптувати зміст освіти у вищій школі до директив ЄC [11]. Важливим i переламним стало приєднання Словаччини до Свропейського Союзу, протягом підготовчого періоду до цього система державного управління, у тому числі вищою освітою, підлягала реформуванню та адаптації (Закони 209/2002, 401/2002, 442/2003, 465/2003, 528 / 2003) [1; 5; 6]. Зміни були спрямовані на усунення технічних недоліків та ухвалення необхідних рішень у ході підготовки приєднання до Європейського Союзу. Пізніше до закону було знову внесено низку змін (Закони $365 / 2004,455 / 2004,523 / 2004,578 / 2004$, 5/2005, 332/2005, 363/2007, 175/2008, 462/2008, 469/2009). Нове законодавство запровадило такі фундаментальні положення $[1 ; 8]$ :

- розподіл освіти і типів вищих навчальних закладів на університетський та неуніверситетський (спеціалізований) сектори, запроваджено поняття дослідницького університету, яке потім було дещо трансформовано;

- адаптація функціонування іноземних університетів, які отримують державний дозвіл (ліцензію) на функціонування у Словаччині у статусі приватних навчальних закладів;

- вплив на діяльність та повноваження органів академічного самоврядування;

- започаткування приватних університетів після отримання державного дозволу (ліцензії) - з 1999 р.;

- змінено механізм фінансування вищої освіти;

- збережено безоплатне навчання для студентів, запроваджено реєстр студентів та реєстр роботодавців;

- зміни в акредитації: навчальний процес у ВНЗ може відбуватися тільки за акредитованими програмами; акредитація навчальних закладів відбувається без класифікації;

- дозволено студентську мобільність, при цьому студенти отримали право змінювати навчальну програму під час навчання; 
- запроваджено інші нові плати для додаткового навчання. У 2005-2007 pp. словацькі вищі навчальні заклади були оцінені Європейською асоціацією університетів [10], ця доповідь мала важливе значення для подальших демократизаційних процесів у системі вищої освіти та управління галуззю. У 2006 р. наступний новий уряд декларує потребу нової стратегії вищої освіти та подальші зміни у вищій освіті, але

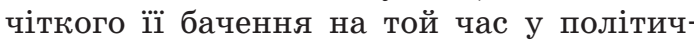
них колах не було. Протягом наступних 4 років стратегії так і не було вироблено, загальні принципи функціонування системи так і залишилися. Незважаючи на практику широкої дворівневої децентралізації управління вищою освітою, на той час у Словаччині збереглася централізація університетського управління, т.зв. академічна олігархія [5]. Керівники ВНЗ, академічна верхівка (ректори) впливають на формування зовнішніх органів управління, тобто Наглядової ради: ректори подають кандидатури 6 членів з 13 та надають пропозиції щодо інших 6-ти членів, яких призначає Міністерство освіти, і 1 члена пропонує академічний сенат. Дослідження Р. Кралікової свідчать, що «усі члени Наглядової ради наближені до ректора, відповідно вони не зацікавлені суперечити йому... хоча правління/Наглядова рада має висловлювати і враховувати інтереси усієї спільноти в управління ВНЗ» [5, с.20]. Така ситуація загрожує встановленню монополії ректора, а будь-які монополії є викривленням демократичного врядування та не відповідають принципам good governance.

2.3. Стратегія реформування до $2020 \mathrm{p}$.

У 2010 р. наступний новий уряд, були розроблені суттєві зміни до закону відповідно до реформи, але вони так і не були ухвалені. У 2012 р. відбулися дострокові парламентські вибори, знову сформовано новий уряд. У 2013 р. було зроблено комплексну оцінку розвитку системи вищої освіти з 2002 р. і розроблена нова стратегія для системи освіти в цілому (включаючи вищу освіту). Цю стратегію було представлено для широкого громадського обговорення, і з урахуванням великої кількості пропозицій подано до Уряду [3], деякі положення увійшли до Національної програми реформ [9].

3. Державне управління вищою освітою у Словаччині: повноваження держави (уряду, міністерства) на системному та вплив на інституційний рівень функціонування вищої освіти.

Повноваження і діяльність уряду та профільного міністерства чітко визначає Закон про вищу освіту (2002), зокрема Глава 11, стаття 102.

Так, Уряд, за поданням міністра, призначає та звільняє голову, заступника та інших членів Акредитаційної комісії затверджує Статут Акредитаційної комісії, надає або позбавляє державного дозволу на діяльність приватних вищих навчальних закладів, обговорює стан вищої освіти та розвиток вищих навчальних закладів [8].

Сфера діяльності Міністерства освіти, науки, досліджень і спорту Словацької Республіки, його компетенції, внутрішня організація, відносини з іншими центральними органами державного управління, іншими інституціями, юридичними і фізичними особами визначається Законом і Статутом Міністерства [12]. Стаття 4 окреслює основні завдання Міністерства у вищій освіті, які укладені відповідно до пункту 2 статті 102 Закону [8, с.83-86]: «Міністерство повинно:

- створювати умови для розвитку вищих навчальних закладів та вищої освіти; відповідає за оновлення та вдосконалення законодавчої бази у сфері вищої освіти,

- щорічно готує оновлення та публікує довгострокову стратегію розвитку освіти, досліджень, творчих та інших видів діяльності вищих навчальних закладів (далі - довгострокова стратегія Міністерства). Довгострокова стратегія Міністерства укладається на період від 5 до 10 р.,

- готує та публікує щорічний звіт про сучасний стан вищої освіти; визначає дату та форму подання щорічного звіту про діяльність та звіт про фінансове управління вищого навчального закладу,

- обговорює та переглядає довгострокову стратегію публічних ВНЗ та довгострокові стратегії приват- 
них ВН3, встановлюе дату і форму подання цієї довгострокової стратегії, - визначає субсидії для вищих навчальних закладів з державного бюджету після попередньої консультації 3 представниками представницьких органів вищої освіти,

- ухвалює рішення після попередньої консультації з представницькими органами ВНЗ, коли необхідно, щодо зменшення кількості стаціонарних місць, на які міністерство повинно надати фінансування до ВНЗ; обмеження відсотка студентів стаціонарної форми навчання у ВНЗ не може бути менше за $5 \%$,

- реєструє (затверджує) вибрані внутрішні регуляційні документи (статути),

- ухвалює рішення, після погодження Акредитаційною комісією, щодо надання права ВНЗ присуджувати науковий ступінь після успішного завершення відповідної програми, надавати права ВНЗ впроваджувати напрямок докторських студій і процедуру захисту дисертації та присуджувати звання професора; надавати право навчальному закладу, який не є вищим, брати участь у реалізації $\mathrm{PhD}$ програми. Якщо Міністерство ухвалює рішення, відмінне від рішення Акредитаційної комісії, воно його обгрунтовує та оприлюднює аргументацію ухваленого рішення,

- подає Уряду пропозиції щодо змін до переліку ВН3,

- слідкувати за дотриманням загальнообов'язкового законодавства у сфері вищої освіти,

- перевіряє використання фінансів публічних ВНЗ; перевіряє використання коштів приватних ВНЗ, отриманих з державного бюджету,

- подає пропозиції Уряду щодо надання державної згоди для діяльності приватного ВНЗ,

- укладає перелік напрямків підготовки,

- узагальнює та використовує інформацію зі студентських реєстрів ВНЗ,

- визнає дипломи, видані іноземними ВНЗ або іншими інституціями,

- забезпечуе умови та фінансування діяльності Акредитаційної комісії та представницьких органів ВНЗ,
- регулює спеціальними документами умови фінансового та матеріального забезпечення іноземців, які навчаються у Словаччині та словацьких громадян під час навчання за кордоном,

- регулює спеціальними актами додаткове педагогічне навчання для підвищення кваліфікації вчителів» та ін. [8; 12].

Крім цього, міністр визначає розмір заробітної плати ректорам публічних ВНЗ і за зверненням ВНЗ робить подання до Президента Республіки щодо присвоєння звання професора; за пропозицією представницьких органів ВНЗ, подання до Уряду щодо призначення членів Акредитаційної комісії та ін.

Вищі навчальні заклади захищені законом від неправомірних дій міністерства, наприклад, якщо міністр не затверджує або відхиляє статут ВНЗ, тоді університет або ж факультет має право вирішити це питання у Верховному Суді Словацької Республіки. Натомість і академічне середовище, і студенти захищені від свавілля ректорів та порушення ними чинного законодавства. Закон містить норму щодо обмеження або припинення повноважень органів управління університетом, якщо певними заходами або рішеннями порушуються чинне законодавство та академічні права і свободи. Причому це стосується як державних ВНЗ, так і приватних (Стаття 104 Закону). За Статутом Міністерство створює систему моніторингу та прогнозування освіти, здійснює наглядовий аудит за умовами акредитації [12].

Крім цього, як і в усіх країнах-членах ЄC, важливою функцією Міністерства є забезпечення участі Словацької Республіки у програмах ЄC.

Міністерство повинно також виконувати завдання, пов'язані з формуванням державного бюджету, у сфері управління державним майном, законодавчою активністю, у сфері кризового регулювання та захисту секретної інформації, у галузі міжнародних відносин та з європейських питань та ін.

Міністерство освіти, науки, досліджень і спорту Словацької Республіки щорічно складає два стратегічні документи, одним з яких є Річний урядовий звіт про 
стан вищої освіти. Річний звіт про стан вищої освіти містить загальну інформацію про систему вищої освіти (кількість студентів і випускників, процедури прийому), підтримку наукових досліджень, розробок та іншої творчої діяльності в університетах, про систему соціальних гарантій і захисту студентів, крім того, увага приділяється змінам у нормативноправовій базі у сфері вищої освіти і науки, питанням фінансування та управління державними університетами [3].

Відповідно до Закону про вищу освіту (Стаття 102, пункт 2б) профільне $\mathrm{Mi}$ ністерство зобов'язано складати, щороку оновлювати та оприлюднювати Довгострокову стратегію в галузі освіти, наукових досліджень і розробок, художньої та іншої творчої діяльності вищих навчальних закладів. У цій Стратегії визначається план (наміри) діяльності $\mathrm{Mi}$ ністерства на 5-10 р., а також урядові заходи. Ця стратегія є базовою для визначення видатків на розвиток університетів [13]. Цей план Міністерства складається із семи частин: перша частина присвячена місії університетів, 3 другого по п'ятий - окремі аспекти державної політики у сфері вищої освіти та функціонування системи, включаючи і структуру фінансування державних університетів, шостий розділ присвячений іншим видам діяльності університетів і остання частина підсумовує довгострокові наміри міністерства. У Стратегії наголошується, що Міністерство поважає університетську автономію та самоврядність, тому ряд завдань, які воно ініціюватиме, буде грунтуватися на добровільній участі університетів та відповідним стимулюванням університетів, за допомогою фінансових інструментів зокрема. Так, у п.17 Міністерство визначає пріоритети своєї діяльності: «Зосередити увагу на якості вищої освіти при збереженні її доступності, ініціювати проекти, щоб краще інтегрувати навчальний план з практичними потребами, зосередитися на вимірюванні результатів навчання i, враховуючи демографічну ситуацію прогнозовані економічні зміни, й у тому числі на ринку праці, розвивати форми і методи навчання, які будуть спрямовані на громадян середнього і старшого віку з багаторічним досвідом роботи» [3].

Для формування дієвої державно-громадської моделі управління надзвичайно важливим $є$ унормування в чинному законодавстві переліку національних представницьких органів від академічної громадськості або інших стейкхолдерів. Так, Закон про вищу освіти Словаччини, зокрема Глава 12, стаття 107, визначає три представницьких організації у вищій освіті - Рада з вищої освіти, Студентська рада, Конференція ректорів Словацької Республіки [7, с. 88-89]. Закон зобов'язуе міністра подавати до цих організацій для затвердження або надання коментарів i пропозицій щодо питань, які стосуються вищої освіти, а також фінансово забезпечувати діяльність цих органів, причому закон вимагає від держави відшкодування витрат членам цих організацій, які пов'язані з виконанням функцій, визначених законодавством.

Рада $з$ вищої освіти є найвищим органом самоврядування вищих навчальних закладів. Рада з вищої освіти складається 3 представників вищих навчальних закладів і факультетів, обраних академічними сенатами вищих навчальних закладів та академічними сенатами факультетів. Така структура з двох інституційних типів - усього закладу та факультетів окремо - значно посилює позицію факультетів і в системі управління, і у впливі деканів на формування освітньої політики, і у процесі прийняття управлінських рішень з різних питань. Причому кількісно факультетів, звичайно, більше, що теж впливає на специфіку діяльності Ради.

Студентська рада є вищим представницьким органом студентів вищих навчальних закладів. Рада студентів представляє інтереси студентів, ї̈ членами можуть бути тільки студенти вишів. Закон встановлює механізм обрання членів: 1 - від студентської частини Академічного сенату ВНЗ, інші - обираються студентами у пропорції 1 обраний представник на кожні 2000 студентів.

Словацька конференція ректорів є органом, що складається 3 ректорів вищих навчальних закладів. Вона координує i 
підтримуе діяльність ректорів з метою формування спільної політики у сфері вищої освіти. Членами Конференції ректорів є ректори публічних, державних та приватних ВНЗ Словацької Республіки. Якщо приватний вищий навчальний заклад не має посади ректора, його представляє у Конференції визначений статутом представник [14].

Конференція ректорів координує та сприяє співпраці між ректорами, обговорює та висловлює позицію 3 питань, що стосуються освітньо-наукової політики, формулює пропозиції до загальнообов'язкових законодавчих документів, які безпосередньо стосуються вищої освіти або інших нормативно-правових актів, стандартів 3 цієї ж тематики; створює умови для співпраці університетів Словаччини та взаємного обміну інформацією між ними; встановлює та підтримує контакти 3 національними конференціями ректорів в інших країнах та Європейською асоціацією університетів.

Офіційними органами Конференції ректорів є її Президент, який діє від імені Конференції, та Президія (виконавчий орган), яка працює між з'їздами. Діяльність Конференції ректорів організовує та адмініструє Секретаріат, очолюваний Ceкретарем, який підпорядковується Президенту $[14 ; 8]$.

Окремо функціонує Акредитаційна комісія, яка $є$ дорадчим органом уряду Словаччини, Державне агентство досліджень і розвитку Словаччини, кілька національних інститутів - Національний інститут освіти, Національний інститут інформації та прогнозування в освіті та iн.

Університетська автономія у вищій освіті Словаччини, за результатами дослідження Європейської асоціації університетів, має середньо-високі показники у фінансовій автономії (7 місце, $70 \%$ ), і середньо-низька більш обмежена (а відтак більш регульована державою) - організаційна (26 місце, 45\%), кадрова (24 місце, $54 \%$ ) та у навчальному процесі (18 місце, $56 \%$ ) [4]. Фінансова автономія університетів виявляється у тому, що система державного фінансування є гнучкою, по- будована за принципом блок-грантів, які поділяються на широкі категорії. Університети мають право розпоряджатися своїми фінансами, у тому числі залишками на рахунках, продавати нерухомість, брати позики на великі суми [4].

За оцінкою Європейської асоціації університетів, викликом для системи $\epsilon$ управління вищими навчальними закладами є те, «процес прийняття рішень контролюється на багатьох рівнях великою кількістю органів, університетського та факультетського рівнів, які мають обмежені повноваження для того, щоб реагувати на міжнародні та національні виклики... через брак гнучкості, міжфакультетської співпраці та стратегічних ініціатив" [10, с. 28].

На рівні університету система управління теж має свої особливі риси, основними органами управління на інституційному рівні є академічний сенат, ректор та наукова рада $[2$, с.31; 7]. Ректор, якого обирає академічний сенат та призначає Президент Словацької Республіки, розробляє та подає сенату довгострокову стратегію розвитку університету. Декани факультетів, яких призначає ректор та обирає сенат факультету (рада факультету), роблять те саме, тільки на рівні факультетів. До складу Сенату як найвищого органу самоврядування ВНЗ, входять викладачі, адміністративні працівники та студенти. Сенат затверджує пропозицію ректора щодо кандидатур на членів Наглядової ради. Національними пріоритетами на найближчі роки є подальше реформування у напрямку якості як освіти, так і кадрів, у тому числі керівних, акредитаційна реформа, оптимізація типів ВНЗ та подальша європеїзація та демократизація [9].

Висновки. Реформи національної системи вищої освіти та освітнього законодавства Словаччини за 25 років трансформували і систему управління, перерозподіливши повноваження та сфери відповідальності між державою та академічними стейкхолдерами різних груп. Варто особливо наголосити на таких відмінних рисах: 1) децентралізація і в територіальному, і в політичному плані, а також масовизація та регіоналізація 
на початку реформ сприяли створенню сильних регіональних університетів, що позитивно вплинуло на демократизацію та економічно-соціальний розвиток усієі території Словаччини; 2) створення моделі автономії за принципом незалежності університетів від міністерства, а факультетів від університету та надання широких прав та свобод базовому рівню у системі вищої освіти - факультету, підтримка академічного середовища у широкому розумінні з боку міністерства у певні періоди відіграло важливу роль у ментально-ціннісних перетвореннях та європеїзації самого академічного середовища, що стало доброю передумовою для змін в університетському менеджменті; 3) запровадження університетської автономії, зокрема фінансової та надання майнових прав університетам, сприяло фінансовій стабілізації вищої школи; 4) при широких правах і свободах, держава (уряд і міністерство) за законом зберегли за собою право у демократичних формах брати участь в управлінні ВНЗ завдяки створеній системі впливів і противаг (що унеможливлює монополізацію управління академічною олігархією): наприклад, механізм формування Наглядових рад є інструментом впливу і своєрідного контролю міністерства за процесом утворення юридичних осіб та фінансовими операціями університетів, щоб мінімізувати зловживання у цій сфері. Для України як країни, яка має високе корупціогенне поле та ризики «феодалізації» університетів, цей досвід може стати прикладом добрих практик у сфері врядування, тимчасових кроків у період трансформацій, який варто вивчати і формувати 3 його урахуванням найефективніші розв'язання для управлінських рішень щодо вищої освіти і науки у національній освітній політиці.

СПИСОК АIТЕРАТУРИ:

1. Benova E., Fabus M. Systemic processes of democratization of higher education in Slovakia / E. Benova, M. Fabus // Збірник наукових праць Буковинського університету. Економічні науки. - 2012. - Вип.8. [Електронний ресурс]. - Режим доступу: http://www.bukuniver. edu.ua/Applications/zbirnik/n8/12SPD.pdf, accessed 26.08.2015.

2. De Boer, H. and File, J. (2009) Higher Education Governance Reform Across Europe. Enschede: CHEPS, University of Twente. -31 p.

3. Dlhodobý zámer ministerstva a jeho aktualizácie https://www.minedu.sk/dlhodoby-zamerministerstva-a-jeho-aktualizacie/, accessed 26.08.2015.

4. EUA Institutional Autonomy in Europe II. The Scorecard (2010) [Електронний ресурс]. - Peжим доступу: http://www.university-autonomy.eu/countries/slovakia/, accessed 26.08.2015 5. Kralikova, Renata. Different faces of one higher education governance model. How do the domestic actors translate supranational trends within European context? [Електронний ресурс]. - Режим доступу: http://ecpr.eu/filestore/paperproposal/b4b68907-7269-4fe1-a411f4bf $4 \mathrm{~b} 7555 \mathrm{c} 0$.pdf, access 20.08.2015.

6. Malova Darina, Lastic Eric. Higher Education in Slovakia: A Complicated Restoration of Liberal Rules / Darina Malova, Eric Lastic // East European Constitution Review, Summer 2000. - pp. 100-104.

7. Mederly P. The Role of the State in Development of Academic Autonomy and Funding of Higher Education Institutions in Slovakia [Електронний ресурс]. - Режим доступу: http:// www.eua.be/Libraries/ATHENA/3 Peter Mederly ATHENA CW UA Slovak example. sflb.ashx, access 26.08.2015.

8. National Council of the Slovak Republic (2002), Law No.131 of 21 February 2002 on Higher Education and on Changes and Supplements to Some Laws, [Електронний ресурс]. - Режим доступу: http://www.astu.tuke.sk/dokumenty/L_131.pdf, accessed 26.08.2015.

9. National Reform Programme of the Slovak Republic for 2011-2014, [Електронний ресурс]. - Режим доступу: http://ec.europa.eu/europe2020/pdf/csr2014/nrp2014_slovakia_en.pdf, access 28.08.2015.

10. The Slovak higher education system and its research capacity. EUA sectoral report / Henrik Toft Jensen, Alojz Kralj, Don McQuillan, Sybille Reichert [Електронний ресурс]. - Peжим доступу: http://www.eua.be/fileadmin/user_upload/files/newsletter/Slovakia_Sector EvaluationReport_080208.pdf , accessed 26.08.2015.

11. The Slovak Republic Bologna National Report (2005) [Електронний ресурс]. - Режим доступу: http://www.ehea.info/Uploads/Documents/National_Report_Slovak_Republic_05. 
pdf, accessed 26.08.2015.

12. Štatút Ministerstva školstva, vedy, výskumu a športu Slovenskej republiky [Електронний ресурс]. - Режим доступу: https://www.minedu.sk/statut-ministerstva-skolstva-vedyvyskumu-a-sportu-sr/, accessed 26.08.2015.

13. Web page of the Ministry of Education of the Slovak Republic [Електронний ресурс]. - Peжим доступу: https://www.minedu.sk/about-the-ministry/, accessed 26.08.2015.

14. Web page of the Slovak Rectors' Conference [Електронний ресурс]. - Режим доступу: http://www.srk.sk/en/about, accessed 26.08.2015.

\section{REFERENCES:}

1. Benova E., Fabus M. Systemic processes of democratization of higher education in Slovakia // Zbirny`k naukovy`x pracz` Bukovy`ns`kogo universy`tetu. Ekonomichni nauky` - 2012. - № 8. Access mode: http://www.bukuniver.edu.ua/Applications/zbirnik/n8/12SPD.pdf, accessed 26.08.2015.

2. De Boer, H. and File, J. (2009) Higher Education Governance Reform Across Europe. Enschede: CHEPS, University of Twente. $-31 \mathrm{p}$.

3. Dlhodobý zámer ministerstva a jeho aktualizácie https://www.minedu.sk/dlhodoby-zamerministerstva-a-jeho-aktualizacie/, accessed 26.08.2015.

4. EUA Institutional Autonomy in Europe II. The Scorecard (2010) Access mode: http://www. university-autonomy.eu/countries/slovakia/, accessed 26.08.2015

5. Kralikova, Renata. Different faces of one higher education governance model. How do the domestic actors translate supranational trends within European context? Access mode: http://ecpr.eu/filestore/paperproposal/b4b68907-7269-4fe1-a411-f4bf4b7555c0.pdf, access 20.08.2015.

6. Malova Darina, Lastic Eric. Higher Education in Slovakia: A Complicated Restoration of Liberal Rules / Darina Malova, Eric Lastic // East European Constitution Review, Summer 2000. - pp. 100-104.

7. Mederly P. The Role of the State in Development of Academic Autonomy and Funding of Higher Education Institutions in Slovakia Access mode: http://www.eua.be/Libraries/ATHENA/3_Peter_Mederly_ATHENA_CW_UA_Slovak_example.sflb.ashx, access 26.08.2015.

8. National Council of the Slovak Republic (2002), Law No.131 of 21 February 2002 on Higher Education and on Changes and Supplements to Some Laws, Access mode: http://www.astu. tuke.sk/dokumenty/L 131.pdf, accessed 26.08.2015.

9. National Reform Programme of the Slovak Republic for 2011-2014, Access mode: http:// ec.europa.eu/europe2020/pdf/csr2014/nrp2014_slovakia_en.pdf, access 28.08.2015.

10. The Slovak higher education system and its research capacity. EUA sectoral report / Henrik Toft Jensen, Alojz Kralj, Don McQuillan, Sybille Reichert Access mode: http://www.eua.be/ fileadmin/user_upload/files/newsletter/Slovakia_Sector EvaluationReport_080208.pdf , accessed 26.08.2015.

11. The Slovak Republic Bologna National Report (2005) Access mode: http://www.ehea.info/ Uploads/Documents/National_Report_Slovak_Republic_05.pdf, accessed 26.08.2015.

12. Štatút Ministerstva školstva, vedy, v'́skumu a športū Slovenskej republiky Access mode: https://www.minedu.sk/statut-ministerstva-skolstva-vedy-vyskumu-a-sportu-sr/, accessed 26.08.2015.

13. Web page of the Ministry of Education of the Slovak Republic Access mode: https://www. minedu.sk/about-the-ministry/, accessed 26.08.2015.

14. Web page of the Slovak Rectors' Conference Access mode: http://www.srk.sk/en/about, accessed 26.08.2015.

\section{Дегтярьова Ірина Олександрівна - докторант}

Дніпропетровський регіональний інститут державного управління Національної академії державного управління при Президентові України

Адреса: 49044, м. Дніпропетровськ, вул. Гоголя, 29

E-mail: irenkadnepr@ukr.net

Degtyarova Iryna Oleksandrivna - doctoral candidate

Dnepropetrovsk regional institute of public administration, the National academy of public administration, office of the President of Ukraine

Address: 29, Gogol Str., Dnipropetrovsk, 49044, Ukraine

E-mail: irenkadnepr@ukr.net 